\title{
THE PROTECTIVE EFFECTS OF RED CHILLI AGAINST CARCINOGENICITY IN THE ALBINO RATS
}

by

M.K.E. Youssef ${ }^{a}$, S.M. El-Bendary ${ }^{b}$,

N.T. El-Melegy ${ }^{\mathrm{c}}$, R.M. Ahmed ${ }^{\mathrm{d}}$

a Faculty of Agriculture, Food Science \& Technology Dept., Assiut University, 71516 Assiut, Egypt

${ }^{b}$ Faculty of Specific Education, Home Economic Dept., Ain Shams University, Cairo, Egypt

${ }^{c}$ Faculty of Medicine, Medical Biochemistry Dept., Assiut University, 71516 Assiut, Egypt

${ }^{d}$ Faculty of Specific Education, Home Economic Dept., Assiut University, 71516 Assiut, Egypt

مجلة بحوث التربية النوعية - جامعة المنصورة

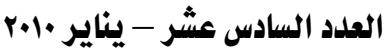


= The Protective Effects of Red Chilli against Carcinogenicity in the Albino Rats 
THE PROTECTIVE EFFECTS OF RED CHILLI

\title{
AGAINST CARCINOGENICITY IN THE ALBINO RATS
}

\author{
by \\ M.K.E. Youssef ${ }^{\mathrm{a}}$, S.M. El-Bendary ${ }^{\mathrm{b}}$, N.T. El-Melegy ${ }^{\mathrm{c}}$, R.M. Ahmed ${ }^{\mathrm{d} 1}$
}

\begin{abstract}
Red chilli was irradiated with two types of radiations; gamma and microwave. The effects of gamma and microwave technology on the anticarcinogenic properties of red chilli and its possible use as a helpful agent in the treatment of cancer were investigated. Biochemical studies indicated that the carcinogenic effect of 1,2-dimethylhydrazine (DMH) treatment was significantly modulated on red chilli supplementation as indicated by the observed significant changes of serum levels of vascular endothelial growth factor (VEGF) and Tissue inhibitors of metalloproteinases-1 (TIMP-1) particularly with gamma irradiated red chilli. The results of this study suggested that red chilli had a beneficial effect on chemically induced cancer in rats. The study might provide an effective dietary chemopreventive approach to disease management.
\end{abstract}

Keywords: Red chilli, DMH, VEGF, TIMP-1

${ }^{a}$ Faculty of Agriculture, Food Science \& Technology Dept., Assiut University, 71516 Assiut, Egypt

${ }^{b}$ Faculty of Specific Education, Home Economic Dept., Ain Shams University, Cairo, Egypt

${ }^{c}$ Faculty of Medicine, Medical Biochemistry Dept., Assiut University, 71516 Assiut, Egypt

${ }^{d}$ Faculty of Specific Education, Home Economic Dept., Assiut University, 71516 Assiut, Egypt 


\section{Introduction}

Cancer is increasing at an alarming rate in the world. Diet and dietary constituents had been found to play an important role in carcinogenesis. Several epidemiologic studies had also showed the importance of dietary habits in carcinogenesis and had shown a relationship between dietary intake and the incidence of cancer (Yamamoto, 2000). 1,2Dimethylhydrazine $(\mathrm{DMH})$, a potent and complete carcinogen, had been reliably used to induce initiation and promotion steps of colon carcinogenesis in rodents. DMH and related compounds induce neoplasm specifically in colon of rat even after a single dose (Ward, 1974). Experimental colon cancer induced by $\mathrm{DMH}$ in rats mimics human colon cancer (Halline et al., 1989) and is therefore an ideal model for cancer studies.

Angiogenesis, the formation of new blood vessels from pre-existing endothelium, had been shown to be critically involved in tumor development and progression and predictive for prognosis or clinical stage in most solid tumors that had been assessed (Folkman, 1990). Vascular endothelial growth factor (VEGF), a soluble angiogenic factor produced by many tumor and normal cells, plays a key role in regulating normal and abnormal angiogenesis (Inser \& Asahara, 1999). VEGF is a potent mitogen and chemoattractant for endothelial cells and induces the release of MMP-2, MMP-9, and MT1-MMP by endothelial cells (Velasco, 2002). In addition, VEGF, also known as vascular permeability factor, induces vascular permeability, which allows leakage of plasma proteins, such as fibronectin and other clotting proteins (Dvorak, 2002). Tissue inhibitors of metalloproteinases (TIMPs) is one of the most major inhibitors of MMPs. TIMPs were originally found as collagenase inhibitors in serum and in the conditioned medium from fibroblast cultures (Welgus et al., 1979). There are four TIMPs in humans (TIMP-1 to -4 ) of $22-29 \mathrm{kDs}$. TIMP-1 and TIMP-3 are glycoproteins and TIMP-2 and TIMP-4 do not contain carbohydrates. They inhibit almost all MMPs tested so far (Baker et al., 2002).

Many of the common foods found in grocery stores or organic markets contain cancer-fighting properties, from the antioxidants that neutralize the damage caused by free radicals to the powerful phytochemicals. Many naturally occurring substances of plant origin such as spices in human diet exhibited anticarcinogenic and antimutagenic effects. 


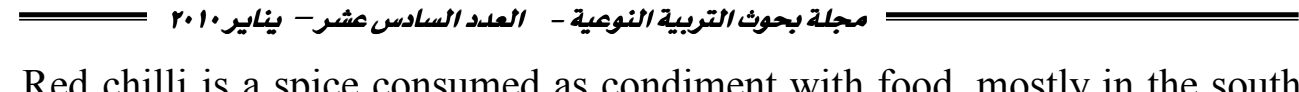

Red chilli is a spice consumed as condiment with food, mostly in the south region of Egypt. Red chilli is the ripened fruit of pepper plant. It is a member of the family Solanecea and its Latin name is Capsicum annuum. Information about red chilli is available from ancient sources. Mayans and Aztecs used it for toothache and for treatment of some diseases. It was reported that 2 drops of red chilli extract cured toothache and sore throat (Boyunaga et al., 1995). In addition, red chilli has many valuable hygienic benefits concerning improvement the digestion of food. Red Chilli consists of $6 \%-7 \%$ glucose, $0.12 \%-35 \%$ carotenoids, nicotinic acid, iron, phosphorus, calcium, protein, water, volatile oils and vitamins $\mathrm{A}, \mathrm{C}$ and $\mathrm{E}$. The active material capsaicin (8-methyl- $N$-vanillyl-6-noneamide), causing the hotness, is an odorless white alkaloid soluble in hot water, alcohols and acetone (Rozin, 1990).

Menon, (1996) studied the effect of red chilli on intestinal Bglucuronidase and faecal mucinase activity in rats given DMH. Min et al., (2004) demonstrated the antiangiogenic activity of capsaicin using in vitro and in vivo assay systems. Capsaicin inhibited both VEGF-induced vessel sprouting in rat aortic ring assay and VEGF-induced vessel formation in the mouse Matrigel plug assay. Moreover, capsaicin was able to suppress tumor induced angiogenesis in chick chorioallantoic membrane assay. Nalini et al., (2006) investigated the effect of red chilli on colon cancer induced in rats by a colon-specific carcinogen, DMH. Colon cancer was induced by subcutaneous injection of DMH at a dosage of $20 \mathrm{mg} / \mathrm{kg}$ of body weight (15 doses, at 1-week intervals). After the total experimental period of 32 weeks (including 2 weeks of acclimatization) the incidence and number of tumors in the colon were observed to be significantly higher in the rats administered $\mathrm{DMH}$ and/or red chilli.

Protecting the safety of our food supply is of higher priority and a greater challenge than at any time in many years. Food sanitization is a process of exposing food to ionising radiation such as gamma rays emitted from the radioisotopes ${ }^{60} \mathrm{Co}$ and ${ }^{137} \mathrm{Cs}$, or microwave produced by machine sources. Numerous studies dealt with detection methods for irradiated or microwaved spices and had also established that irradiation or microwave technology could be considered radiologically, microbiologically and toxicologically safe technology. Nevertheless, questions focusing on nutrient loss and changes of antioxidant (anticarcinogenic) properties after sanitization of spices are still being debated in the scientific field. Since diet 
The Protective Effects of Red Chilli against Carcinogenicity in the Albino Rats

had been correlated with incidence of the cancer disease, our aim was to evaluate the effect of administering raw red chilli and red chillis after treatment by gamma or microwave on the carcinogenicity in albino rats.

\section{Materials and Methods}

\subsection{Source of samples}

Nine kilograms of three samples $(3.0 \mathrm{~kg} / \mathrm{sample})$ of red chilli were procured freshly from the Faculty of Agriculture, Assiut University. The samples were cultivated in the same field in Assiut city and harvested in the same period (January/February 2008). The samples were kept at $5{ }^{\circ} \mathrm{C}$ in aroma-tight bags excluding light. The whole sample was homogenized and was grind in a mill type Lab. Mill-1 QC-114.

\subsection{Treatment of red chilli sample}

One sample of raw red chilli (about 3.0 kilograms) was irradiated at Egyptian Atomic Energy Authority using a ${ }^{60} \mathrm{Co}$ gamma source at an average dose of $10 \mathrm{kGy}$, which is the average dose recommended by the Codex Alimentarius commission (1990), to reduce microbial load or to reduce the number of pathogenic microrganisms for spices and herbs. Another sample of raw red chilli (about 3.0 kilograms) was treated by microwave radiation. The treatment using microwave radiation (MS143SCE, Samsung Electronics, Korea) was performed by continues supply of red chilli in the pasteurization chamber at $50 \mathrm{~W} / \mathrm{Kg}$ of red chilli for $15 \mathrm{~min}$., where microwave oscillators allow the sanitization with drastic reduction of the microbic contamination (Less than $10^{3}$ microorganisms per gram).

\subsection{Preparation of solutions:}

N,N'-Dimethylhydrazine Dihydrochloride (DMH, $30 \mathrm{mg} / \mathrm{kg}$ of body weight) was dissolved in $1 \mathrm{~m} M$ EDTA just prior to use, and the $\mathrm{pH}$ was adjusted to 6.5 with $0.9 \% \mathrm{NaCl}$.

\subsection{Experimental animals}

Fifty adult male white albino rats, weighing between 150 and 175 grams were obtained from the animal house of the Faculty of Medicine, Assiut University. The animals were kept in wire cages under the normal 


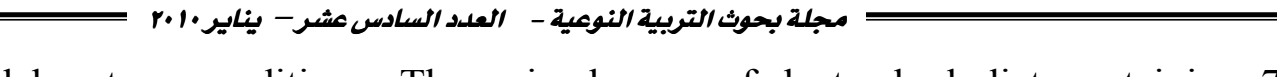

laboratory conditions. The animals were fed standard diet containing 7 $\mathrm{mg} /$ body weight of the studied red chilli samples. This modified powdered diet was fed to rats throughout the experimental period of 18 weeks and 2 weeks prior to the experiment for acclimatization, and tap water was provided. Rats were randomized into 5 groups of 10 animals each. The animals were cared for incompliance with the principles and guidance of Ethical Committee for Animal Care of Assiut University in accordance with the Egyptian National Law on Animal Care and Use. The standard diet used consisted of corn oil, salt mixture, vitamin mixture and cornstarch as described elsewhere (El-Sayed, 2001, Ilwy, 2003 and Anon, 1980).

\subsection{Design of the animal experiment}

The rats were classified randomly according to the type of red chilli sample present in the given diet under investigation into (5) main groups of (10) rats each. Each rat was marked on the tail to differentiate between animals. Daily administrations were continued for (18) weeks. The groups were classified as the following:

Group I: Rats received the vehicle and act as negative control.

Group II: Rats were fed on diet alone for 4 weeks. Then rats injected DMH (30 mg/kg body weight) once a week subcutaneously for more 8 weeks. Rats continually fed with diet alone for other 6 weeks until the end of the program.

Group III: Rats were fed on diet with raw red chilli for 4 weeks. Then rats injected DMH (30 mg/kg body weight) once a week subcutaneously for more 8 weeks. Rats continually fed with diet combined with raw red chilli for other 6 weeks until the end of the program.

Group IV: Rats were fed on diet with gamma red chilli for 4 weeks. Then rats injected DMH (30 $\mathrm{mg} / \mathrm{kg}$ body weight) once a week subcutaneously for more 8 weeks. Rats continually fed with diet combined with gamma red chilli for other 6 weeks until the end of the program.

Group V: Rats were fed on diet with microwave red chilli for 4 weeks. Then rats injected $\mathrm{DMH}(30 \mathrm{mg} / \mathrm{kg}$ body weight $)$ once a week subcutaneously for more 8 weeks. Rats continually fed with diet combined with microwave red chilli for other 6 weeks until the end of the program. 


\subsection{Blood samples:}

Five $\mathrm{ml}$ blood samples were obtained from each rat by vein puncture under complete aseptic conditions. Blood samples were taken into plain tubes, allowed to clot for 2 hours at room temperature before centrifuging for 20 minutes at approximately $1000 \mathrm{x}$ g. Serum samples were stored into aliquots at $-20^{\circ} \mathrm{C}$ till time of assay.

\subsection{Determination of VEGF and TIMP-1 in rats sera:}

Serum levels of rat VEGF were determined by monoclonal antibodybased enzyme-linked immunoassay (ELISA) designed to measure Rat VEGF-A 165 levels (Quantikine, R\&D Systems Inc, Catalog No. RRV00, USA) according to the manufacturer's instructions. Rat TIMP-1 serum levels were determined by an ELISA kit (Quantikine, R\&D Systems Inc, Catalog No. RTM100 USA) according to the manufacturer's instructions.

\subsection{Statistical analysis}

Data were tested for normality and were found to be normally distributed. Accordingly, data are presented as the mean \pm SD. Statistical differences between groups were assessed using paired and unpaired Student $t$ test where appropriate. Repeated measures analysis of variance (ANOVA) was used to compare differences in serial samples. A value of $<0.05$ was considered statistically significant. Recovery was calculated by dividing the detector response of analyte in the sample to the response of analyte reference material. Correlation analysis between the different studied variables was performed using spearman's rank correlation coefficient. All analyses were performed using Statistical Package for Social Sciences (SPSS) software (version 11.0).

\section{Results and Discussion}

To determine antiangiogenic activity of red chilli, its effects on VEGF-induced proliferation of endothelial cells and TIMP-1 were evaluated. Albino rats were pretreated with various types of red chilli before determination of VEGF or TIMP-1. Rats were fed with raw red chilli and by samples treated by microwave and gamma radiations at $7 \mathrm{mg} /$ body weight for 18 weeks. The studied animals were initially fed with red chillis and were consequently injected with $\mathrm{DMH}$ starting from the $5^{\text {th }}$ week till $12^{\text {th }}$ 


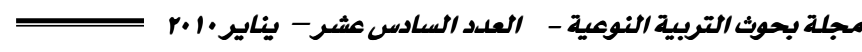

week as a trial to investigate the effect of red chillis on the prevention of cancer.

\subsection{Serum levels of Rat Vascular Endothelial Growth Factor (VEGF):}

The results of the program concerned with the effect of red chillis on the prevention of cancer after 14 weeks are shown in Table (1). Results revealed that the mean serum levels of VEGF for rats treated with red chillis before DMH injection $\left(5^{\text {th }}\right.$ to $12^{\text {th }}$ weeks) were noticeably differed from control group I and DMH group II. There was a decreased levels of VEGF in gamma and microwave red chillis compared to raw red chilli but such difference did not reach the level of the significance.

The results of the program concerned with the effect of red chillis on the prevention of cancer after 18 weeks are shown in Table (2). Results elucidated that the mean serum levels of VEGF for rats treated with red chillis before DMH injection $\left(5^{\text {th }}\right.$ to $12^{\text {th }}$ weeks) were noticeably differed from control group I and DMH group II. Comparing the results, there was a decrease in the level of VEGF of groups IV and V in comparison to group III but the difference did not reach the level of the significance.

\subsection{Serum levels of Rat tissue inhibitor of metalloproteinases 1 (TIMP-1):}

The results of the program concerned with the effect of red chillis on the prevention of cancer after 14 weeks are shown in Table (1). Results revealed that the mean serum levels of TIMP-1 in group III for rats treated with raw red chilli was increased in comparison to control group I and DMH group II but the difference did not reach the significance. However, the mean serum levels of TIMP-1 in groups IV for rats treated with gamma red chilli was significantly increased in comparison to control group I and DMH group II $(\mathrm{P}<0.001)$. Meanwhile, the mean serum levels of TIMP-1 in groups $\mathrm{V}$ for rats treated with microwave red chilli was significantly increased in comparison to control groups I and II $(\mathrm{P}<0.05)$.

There was a significantly increased level of TIMP-1 in gamma red chilli compared to raw red chilli $(\mathrm{P}<0.001)$. However, there was an increased level of TIMP-1 in microwave red chilli compared to raw red chilli but such difference did not reach the level of the significance. 
Meanwhile, there was a significantly increased level of TIMP-1 in gamma red chilli compared to microwave red chilli $(\mathrm{P}<0.001)$.

The results of the program concerned with the effect of red chillis on the prevention of cancer after 18 weeks are shown in Table (2). Results elucidated that the mean serum levels of TIMP-1 for rats treated with red chillis before DMH injection $\left(5^{\text {th }}\right.$ to $12^{\text {th }}$ weeks) were noticeably increased from control groups I and II. In the case of gamma red chilli, the difference is significant at $\mathrm{P}<0.001$ but the difference did not reach the level of significance in the case of microwave and raw red chillis. Comparing the results, there was an increase in the level of TIMP-1 of groups IV and V in comparison to group III but the difference did not reach the level of the significance in the case of microwave red chilli but significant at $\mathrm{P}<0.001$ in the case of gamma red chilli.

There are significant negative correlations between levels of TIMP-1 (14 weeks) \& VEGF (14 weeks), TIMP-1 (14 weeks) \& VEGF (18 weeks), TIMP-1 (18 weeks) \& VEGF (14 weeks) and TIMP-1 (18 weeks) \& VEGF (18 weeks) in the studied groups as shown in Tables from 3 to 6 and figures from 1 to 10 .

There are significant positive correlations between levels of VEGF (18 weeks) Vs VEGF (14 weeks) and TIMP-1 (18 weeks) Vs TIMP-1 (14 weeks) in the studied groups as shown in Tables from 3 to 6 and figures from 1 to 10 .

The carcinogenic effect of DMH treatment was significantly modulated on red chilli supplementation as indicated by the observed significant changes of serum levels of VEGF and TIMP-1 particularly with gamma irradiated red chilli. The results of this study suggest that red chilli has a beneficial effect on chemically induced colonic cancer in rats.

It was well-known that capsaicin inhibits the arylhydrocarbon hydroxylase responsible for the metabolism of carcinogenic polycyclic aromatic hydrocarbons. Capsaicin was also found to suppress the metabolism and covalent DNA binding of polycyclic aromatic hydrocarbons in human and mouse keratinocytes (Modly et al., 1986). In addition, it has been demonstrated that capsaicin modulates the microsomal cytochrome P450 enzymes, thereby affecting the metabolism of carcinogens and other xenobiotics (Teel, 1991). 
An early Italian case-control study revealed that chili consumption was protective against stomach cancer (Buiatti et al, 1989). However, an epidemiologic study showed that chilli pepper consumers have a greater risk to develop stomach cancer than non-consumers (Toth, and Gannett, 1992). A small number of studies have been conducted to assess the carcinogenic potency of chilli (Toth et al., 1984; Toth, and Gannett, 1992). The present study revealed that red chilli has an antiangiogenic activity as presented by significant decrease in VEGF level and significant increase in levels of TIMP-1 in red chilli treated groups. On the cellular level, capsaicin in red chillis almost completely suppressed the stimulatory effect of VEGF on endothelial cell proliferation, migration, and tube formation.

The cytotoxic capacity of the volatile oils based on prooxidant activity can make them excellent antiseptic and antimicrobial agents for personal use. A big advantage of volatile oils shows a very clear antimutagenic capacity which could well be linked to anticarcinogenic activity. Recent studies have demonstrated that the prooxidant activity of volatile oils or some of their constituents is very efficient in reducing local tumor volume or tumor cell proliferation by apoptotic and/or necrotic effects (Paik et al. 2005; Yoo et al., 2005; Kachadourian and Day, 2006). Salim and Fukushima (2003) have shown an antiproliferative activity and inhibition of 1,2-dimethylhydrazine-induced cancer in the rat by volatile oil. Therefore, the sanitization of red chilli by gamma irradiation is more beneficial from the human health point of view than that by microwave where the decreasing amount level of volatile oils is less.

These results could explain the finding that gamma red chilli treated rats showed significant lower levels of VEGF and higher levels of TIMP-1 than other red chilli treated groups. 


\section{Références}

Anon (1980): Second Report of The American Institute of Nutrition. Journal of Nutrition, 11 (8): 1726.

Baker, A.H., Edwards, D.R., Murphy, G. (2002): Metalloproteinase inhibitors: biological actions and therapeutic opportunities. Journal of Cell Science 115 (Pt 19):3719-3727.

Code of Federal Regulation:21CFR179, (2004). Irradiation in the production, processing and handling of food. Title 21 (Vol. 3).

El-Sayed, H.H.M. (2001): Biological studies on effect of Portulaca Oleracea, L. on lowering lipids and blood sugar in experimental animals, Ph. D. Thesis , Faculty of Home Economics, Minufiya University, Minufuya.

Folkman J. (1990): How the field of controlled-release technology began, and its central role in the development of angiogenesis research, Biomaterials, 11, 615-618.

Halline A.G., Dudeja P.K., Lashner B.A., Brasitas T.A. (1989): Urinary excretion of $\mathrm{N}$-acetylspermidine and other acetylated and free polyamines in 1,2-dimethylhydrazine model of experimental rat colon cancer. Cancer Research 49, 4721-4723.

Inser J. M., Asahara T. (1999): Angiogenesis and vasculogenesis as therapeutic strategies for postnatal neovascularization. Journal of Clinical Investigation, 103: 1231-1236.

Ilwy, Y.M.E. (2003): The effect of some kinds of sea food (fish) on blood lipid profile in rats. $\mathrm{Ph}$. D. Thesis, Faculty of Specific Education, Ain Shams University.

Kachadourian, R., Day, B.J., (2006). Flavonoid-induced glutathionedepletion: potential implications for cancer treatment. Free Radical Biological Medicine, 41, 65-76.

Menon, V.P. (1996): Effect of Cocos nucifera and red chilli on intestinal $\beta$ glucuronidase and mucinase activity in experimental colon cancer, Asia Pacific Journal of Clinical Nutrition, 5:96-99.

Min J.-K., Han K.-Y., Kim E.-C., Kim Y.-M., Lee S.-W., Kim O.-H., Kim K.W., Gho Y. S., Kwon Y.-G. (2004): Capsaicin Inhibits in Vitro and in Vivo Angiogenesis, Cancer Research 64:644-651.

Modly, C.E., Das, M., Don, P.S., Marcelo, C.S., Mukhtar, H., Bickers, D.R., (1986). Capsaicin as an in vitro inhibitor of benzo[a]pyrene metabolism and its DNA binding in human and murine keratinocytes. Drug Metabolism Dipososis, 14, 413-416.

Nalini N., Manju V., Menon V.P. (2006): Effect of Spices on Lipid Metabolism in 1,2-Dimethylhydrazine-Induced Rat Colon Carcinogenesis, Journal of Medicinal Food 9:237-245. 


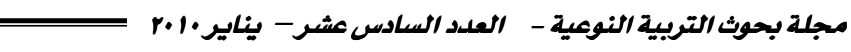

Paik, S.Y., Koh, K.H., Beak, S.M., Paek, S.H., Kim, J.A., (2005). The essential oils from Zanthoxylum schinifolium pericarp induce apoptosis of HepG2 human hepatoma cells through increased production of reactive oxygen species. Biological Pharmaceutical Bulletin, 28, 802-807.

Rozin P. (1990): Getting to like the burn of chili pepper. Biological, physiological. and cultural perspectives. In: Chemical Senses. Vo/ 2: 1rrittrtion (Green BG. Mason JR, Kare MR. eds) Marcel Dekker, New York, 231-269.

Salim, E.I., Fukushima, S., (2003). Chemopreventive potential of volatile oil from black cumin (Nigella sativa L.) seeds against rat colon carcinogenesis. Nutrition Cancer, 45, 195-202.

Teel, R.W., (1991). Effects of capsaicin on rat liver S9-mediated metabolism and DNA binding of aflatoxin. Nutrition Cancer, 15, 27-32.

Toth, B., \& Gannett, P., (1992). Carcinogenicity of lifelong administration of capsaicin of hot pepper in mice. In Vivo (Athens, Greece), 6, 59-63.

Toth, B., Rogan, E., Walker, B., (1984). Tumorigenicity and mutagenicity studies with capsaicin of hot peppers, Anticancer Researh, 4, 117-119.

Welgus, H.G., Stricklin, G.P., Eisen, A.Z., Bauer, E.A., Cooney, R.V., Jeffrey, J.J. (1979): A specific inhibitor of vertebrate collagenase produced by human skin fibroblasts. J. Biol. Chem. 254:1938-1943.

Yamamoto S. (2000): Cancer Statistics Digest. All cancer mortality of prefectures in Japan. JPN J Clin Oncol. 30, 168-175.

Yoo, C.B., Han, K.T., Cho, K.S., Ha, J., Park, H.J., Nam, J.H., Kil, U.H., Lee, K.T., (2005). Eugenol isolated from the essential oil of Eugenia caryophyllata induces a reactive oxygen species-mediated apoptosis in HL-60 human promyelocytic leukemia cells. Cancer Letter 225, 41-52. 
The Protective Effects of Red Chilli against Carcinogenicity in the Albino Rats

Table 1: Serum levels of VEGF and TIMP-1 in DMH treated different red chilli groups and controls (14 weeks)

\begin{tabular}{|c|c|c|c|c|}
\hline \multirow{2}{*}{ Groups $(n=7)$} & \multicolumn{2}{|c|}{ VEGF (pg/mL) } & \multicolumn{2}{|c|}{ TIMP-1 (pg/mL) } \\
\hline & Mean \pm SD & Range & Mean \pm SD & Range \\
\hline $\begin{array}{l}\text { Group I } \\
\text { (Controls) }\end{array}$ & $30.00 \pm 6.56$ & $20.0-40.0$ & $14.14 \pm 4.06$ & $9.0-20.0$ \\
\hline $\begin{array}{c}\text { Group II } \\
(\text { Diet }+ \text { DMH })\end{array}$ & $\begin{array}{c}442.86 \pm 107.91 \\
a^{* * *}\end{array}$ & $300.0-600.0$ & $\begin{array}{c}15.71 \pm 6.92 \\
a^{\neq}\end{array}$ & $9.0-26.0$ \\
\hline $\begin{array}{c}\text { Group III } \\
\text { (raw red chilli }+ \\
\text { DMH) }\end{array}$ & $\begin{array}{c}330.71 \pm 46.23 \\
a^{* * *} b^{* * *}\end{array}$ & $280.0-400.0$ & $\begin{array}{c}28.00 \pm 8.72 \\
\mathbf{a}^{\neq} \mathbf{b}^{\neq}\end{array}$ & $15.0-38.0$ \\
\hline $\begin{array}{c}\text { Group IV } \\
\text { (gamma red chilli + } \\
\text { DMH) }\end{array}$ & $\begin{array}{c}295.00 \pm 37.31 \\
a^{* * *} b^{* * *} c^{\ddagger}\end{array}$ & $230.0-340.0$ & $\begin{array}{c}103.57 \pm 30.78 \\
a^{* * *} b^{* * *} \\
c^{* * *}\end{array}$ & $65.00-160.0$ \\
\hline $\begin{array}{c}\text { Group V } \\
\text { (microwave red chilli } \\
\text { + DMH) } \\
\end{array}$ & 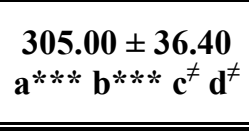 & $250.0-360.0$ & $\begin{array}{c}39.00 \pm 9.42 \\
a^{*} b^{*} c^{\neq} d^{* * *}\end{array}$ & $25.0-50.0$ \\
\hline
\end{tabular}

a: Groups X, XI, XII, XIII versus controls $\quad * * *: \mathrm{P}<0.001 \quad *$ : $\mathrm{P}<0.05$

b: Groups XI, XII, XIII versus Group X $\quad \neq$ : non-significant

c: Groups XII, XIII versus Group XI

d: Group XIII versus Group XII

Table 2: Serum levels of VEGF and TIMP-1 in DMH treated different red chilli groups and controls (18 weeks)

\begin{tabular}{|c|c|c|c|c|}
\hline \multirow{2}{*}{ Groups $(n=7)$} & \multicolumn{2}{|c|}{ VEGF (pg/mL) } & \multicolumn{2}{|c|}{ TIMP-1 (pg/mL) } \\
\hline & Mean \pm SD & Range & Mean \pm SD & Range \\
\hline $\begin{array}{c}\text { Group I } \\
\text { (Controls) }\end{array}$ & $30.00 \pm 6.56$ & $20.0-40.0$ & $14.14 \pm 4.06$ & $9.0-20.0$ \\
\hline $\begin{array}{c}\text { Group II } \\
(\text { Diet + DMH) }\end{array}$ & $\begin{array}{c}480.00 \pm 121.79 \\
a^{* * *}\end{array}$ & $350.0-700.0$ & $\begin{array}{c}17.00 \pm 6.78 \\
a^{\neq}\end{array}$ & $10.0-27.0$ \\
\hline $\begin{array}{c}\text { Group III } \\
(\text { raw red chilli + DMH) }\end{array}$ & $\begin{array}{c}335.00 \pm 44.35 \\
a * * * b^{* * *}\end{array}$ & $300.0-405.0$ & $\begin{array}{c}26.43 \pm 7.48 \\
\mathbf{a}^{\neq} \mathbf{b}^{\neq} \\
\end{array}$ & $15.0-35.0$ \\
\hline $\begin{array}{c}\text { Group IV } \\
\text { (gamma red chilli + } \\
\text { DMH) }\end{array}$ & $\begin{array}{c}320.00 \pm 57.37 \\
\mathbf{a}^{* * *} \mathbf{b} * * * \mathbf{c}^{\neq}\end{array}$ & $210.0-380.0$ & $\begin{array}{c}90.00 \pm 30.41 \\
\mathbf{a} * * * \mathbf{b} * * * \mathbf{c}^{* * *}\end{array}$ & $55.00-150.0$ \\
\hline $\begin{array}{c}\text { Group V } \\
\text { (microwave red chilli }+ \\
\text { DMH) }\end{array}$ & $\begin{array}{c}325.00 \pm 32.53 \\
a^{* * *} b^{* * * * c^{\neq}} \mathbf{d}^{\neq}\end{array}$ & $280.0-370.0$ & $\begin{array}{c}34.14 \pm 8.97 \\
\mathbf{a}^{\neq} \mathbf{b}^{\neq} \mathbf{c}^{\neq} \mathbf{d}^{* * *}\end{array}$ & $20.0-45.0$ \\
\hline
\end{tabular}

a: Groups X, XI, XII, XIII versus controls $\quad * * *: \mathrm{P}<0.001 \quad \neq$ : non-significant

b: Groups XI, XII, XIII versus Group X

c: Groups XII, XIII versus Group XI

d: Group XIII versus Group XII 
Table 3: Correlation analysis between the different studied variables in group II

\begin{tabular}{||c|c|c|c||}
\hline Variables & $\begin{array}{c}\text { VEGF (14 } \\
\text { weeks) }\end{array}$ & $\begin{array}{c}\text { VEGF (18 } \\
\text { weeks) }\end{array}$ & $\begin{array}{c}\text { TIMP-1 (14 } \\
\text { weeks) }\end{array}$ \\
\hline VEGF (18 weeks) & $\mathbf{0 . 9 6 7 7 ^ { * * * }}$ & & \\
\hline TIMP-1 (14 weeks) & $\mathbf{- 0 . 8 6 8 1 *}^{*}$ & $\mathbf{- 0 . 8 3 0 4}^{*}$ & \\
\hline TIMP-1 (18 weeks) & $\mathbf{- 0 . 8 5 0 5}^{*}$ & $\mathbf{- 0 . 8 1 7 2}^{*}$ & 0.9870 \\
\hline
\end{tabular}

VEGF: vascular endothelial growth factor; TIMP-1: tissue inhibitor of metalloproteinases 1 .

$*: \mathrm{P}<0.05 ; * * *: \mathrm{P}<0.001$

Table 4: Correlation analysis between the different studied variables in group III

\begin{tabular}{||c|c|c|c||}
\hline Variables & $\begin{array}{c}\text { VEGF (14 } \\
\text { weeks) }\end{array}$ & VEGF (18 weeks) & TIMP-1 (14 weeks) \\
\hline \hline VEGF (18 weeks) & $\mathbf{0 . 9 8 5 8}^{* * * *}$ & & \\
\hline TIMP-1 (14 weeks) & $\mathbf{- 0 . 9 4 7 1 ~}^{* * * *}$ & $\mathbf{- 0 . 9 4 4 1}^{* * *}$ & \\
\hline TIMP-1 (18 weeks) & $\mathbf{- 0 . 8 9 5 1}^{* *}$ & $-\mathbf{0 . 9 1 6 9}$ & $0.9840^{* * *}$ \\
\hline
\end{tabular}

VEGF: vascular endothelial growth factor; TIMP-1: tissue inhibitor of metalloproteinases 1. $* *: \mathrm{P}<0.01 ; * * *: \mathrm{P}<0.001$

Table 5:Correlation analysis between the different studied variables in group IV.

\begin{tabular}{||c|c|c|c||}
\hline Variables & $\begin{array}{c}\text { VEGF (14 } \\
\text { weeks) }\end{array}$ & $\begin{array}{c}\text { VEGF (18 } \\
\text { weeks) }\end{array}$ & $\begin{array}{c}\text { TIMP-1 (14 } \\
\text { weeks) }\end{array}$ \\
\hline \hline VEGF (18 weeks) & $\mathbf{0 . 9 6 9 5}^{* * *}$ & & \\
\hline TIMP-1 (14 weeks) & $\mathbf{- 0 . 9 0 3 4}^{* *}$ & $\mathbf{- 0 . 9 5 7 8}^{* * *}$ & \\
\hline TIMP-1 (18 weeks) & $\mathbf{- 0 . 9 4 0 1 ~}^{* * *}$ & $\mathbf{- 0 . 9 8 3 8}^{* * *}$ & $0.9880^{* * *}$ \\
\hline
\end{tabular}

VEGF: vascular endothelial growth factor; TIMP-1: tissue inhibitor of metalloproteinases 1. $* *: \mathrm{P}<0.01 ; * * *: \mathrm{P}<0.001$

Table 6: Correlation analysis between the different studied variables in group $V$.

\begin{tabular}{|c|c|c|c||}
\hline Variables & $\begin{array}{c}\text { VEGF (14 } \\
\text { weeks) }\end{array}$ & $\begin{array}{c}\text { VEGF (18 } \\
\text { weeks) }\end{array}$ & $\begin{array}{c}\text { TIMP-1 (14 } \\
\text { weeks) }\end{array}$ \\
\hline \hline VEGF (18 weeks) & $\mathbf{0 . 9 7 8 2 ~}^{* * *}$ & & \\
\hline TIMP-1 (14 weeks) & $\mathbf{- 0 . 7 4 6 4}^{\#}$ & $-\mathbf{0 . 6 7 1 9}$ & \\
\hline TIMP-1 (18 weeks) & $\mathbf{- 0 . 7 6 3 0}^{*}$ & $-\mathbf{0 . 6 7 1 0}$ & $0.9845^{* * *}$ \\
\hline
\end{tabular}

VEGF: vascular endothelial growth factor; TIMP-1: tissue inhibitor of metalloproteinases 1.

$*: \mathrm{P}<0.05 ; * * *: \mathrm{P}<0.001 ; \neq$ : non-significant 


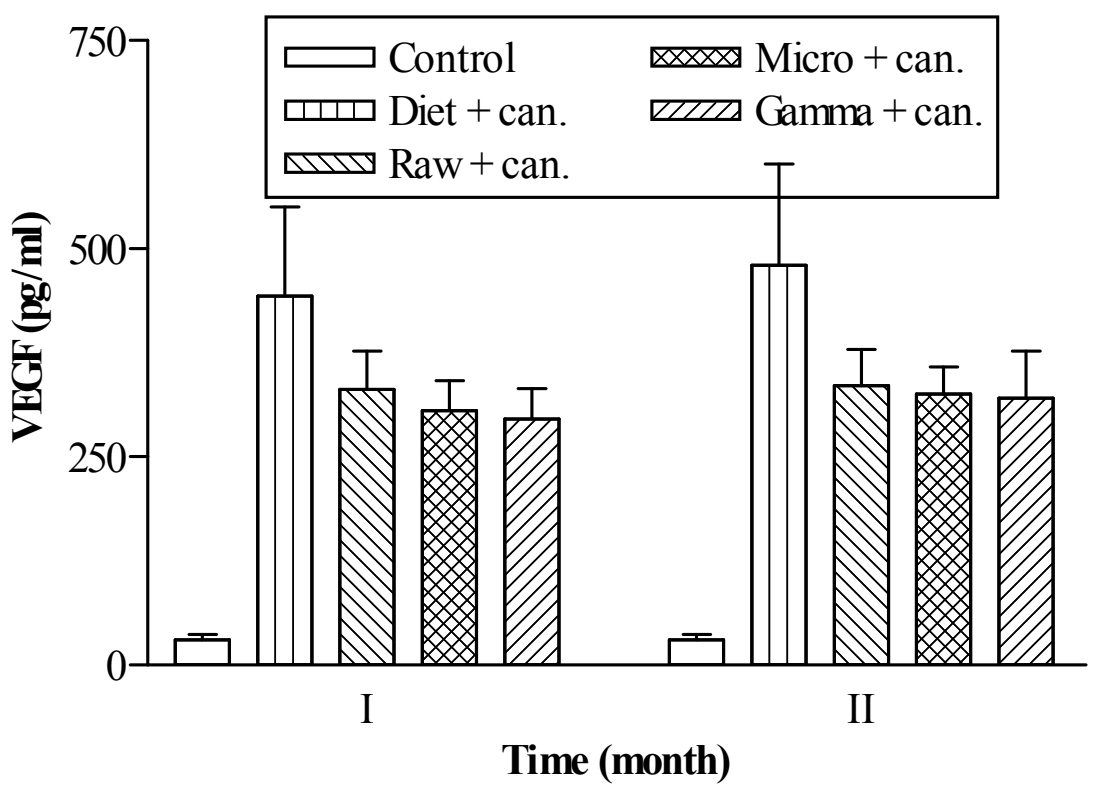

Fig. 1. VEGF levels in different groups.

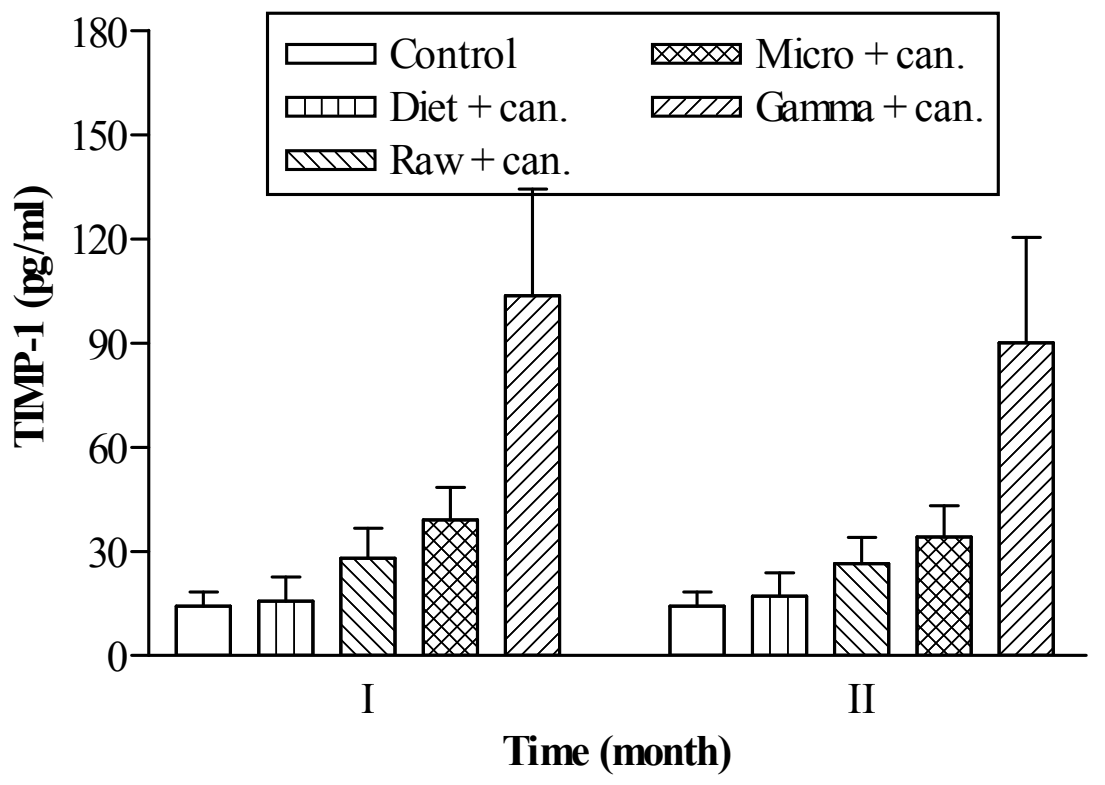

Fig. 2. TIMP-1 levels in different groups. 
مجلة بحوث التربية النوعية - العدد السادس عشر - يناير •l. r

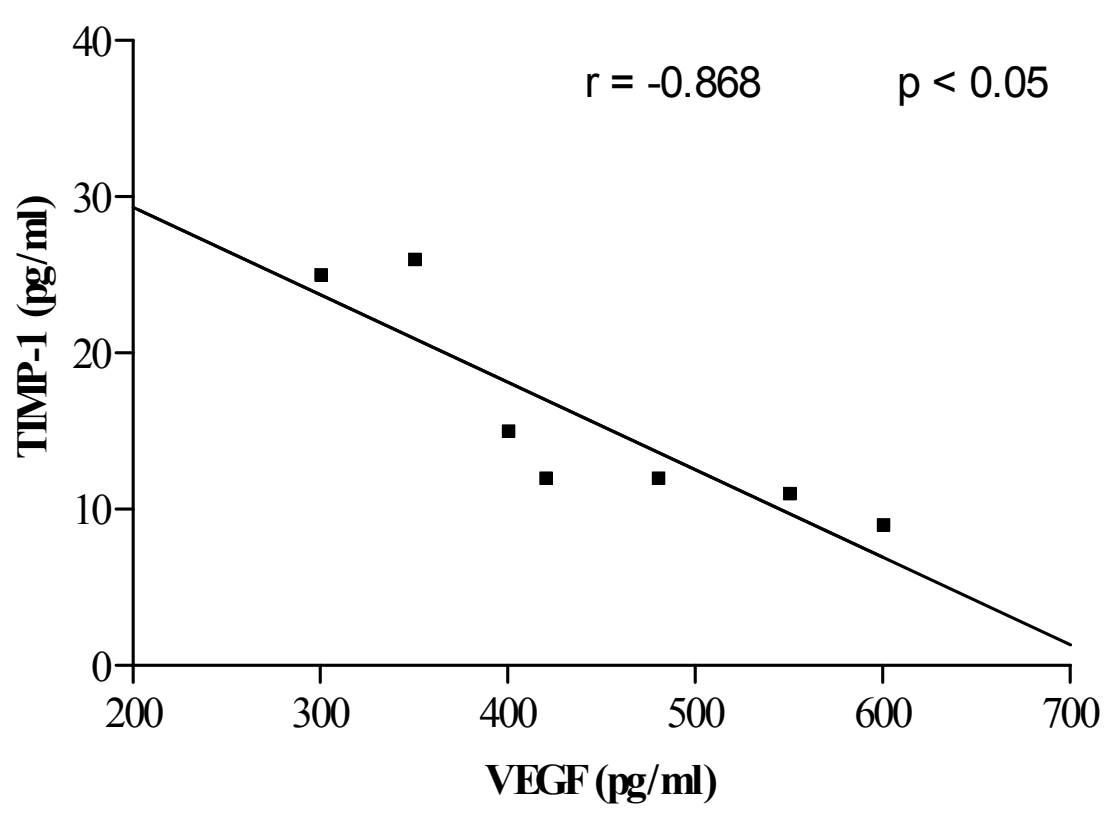

Fig. 3. Correlation between VEGF \& TIMP-1 in diet + DMH group at 1 month.

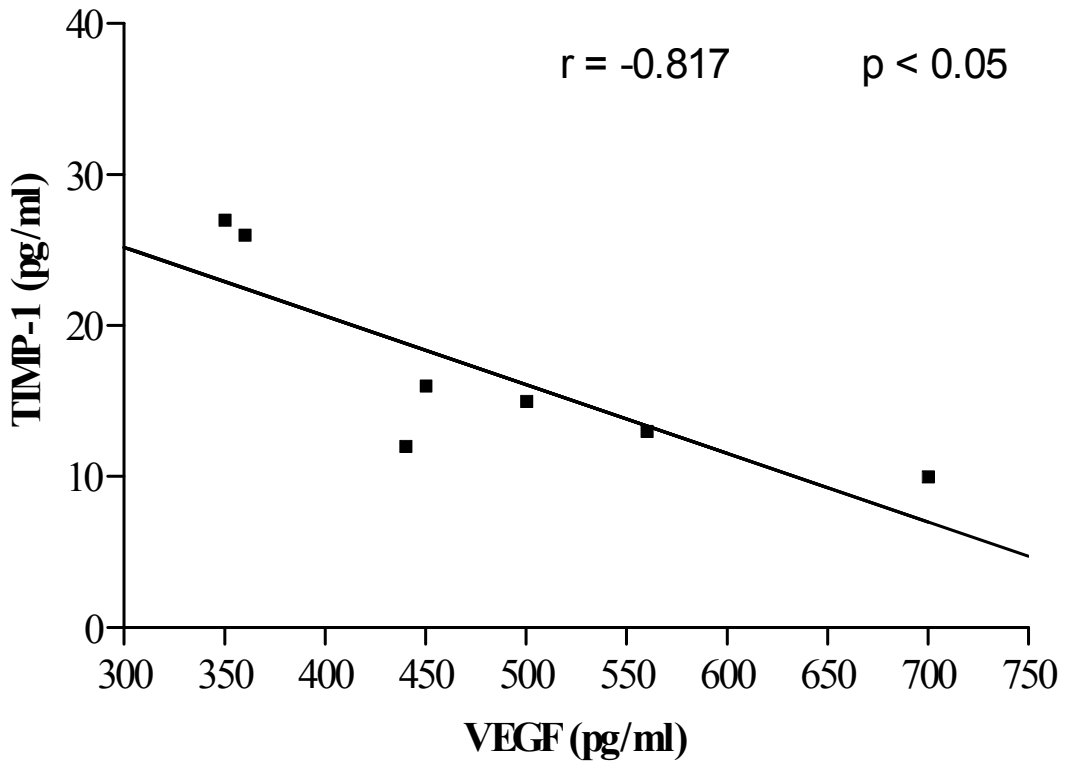

Fig. 4. Correlation between VEGF \& TIMP-1 in diet + DMH group at 2 months. 


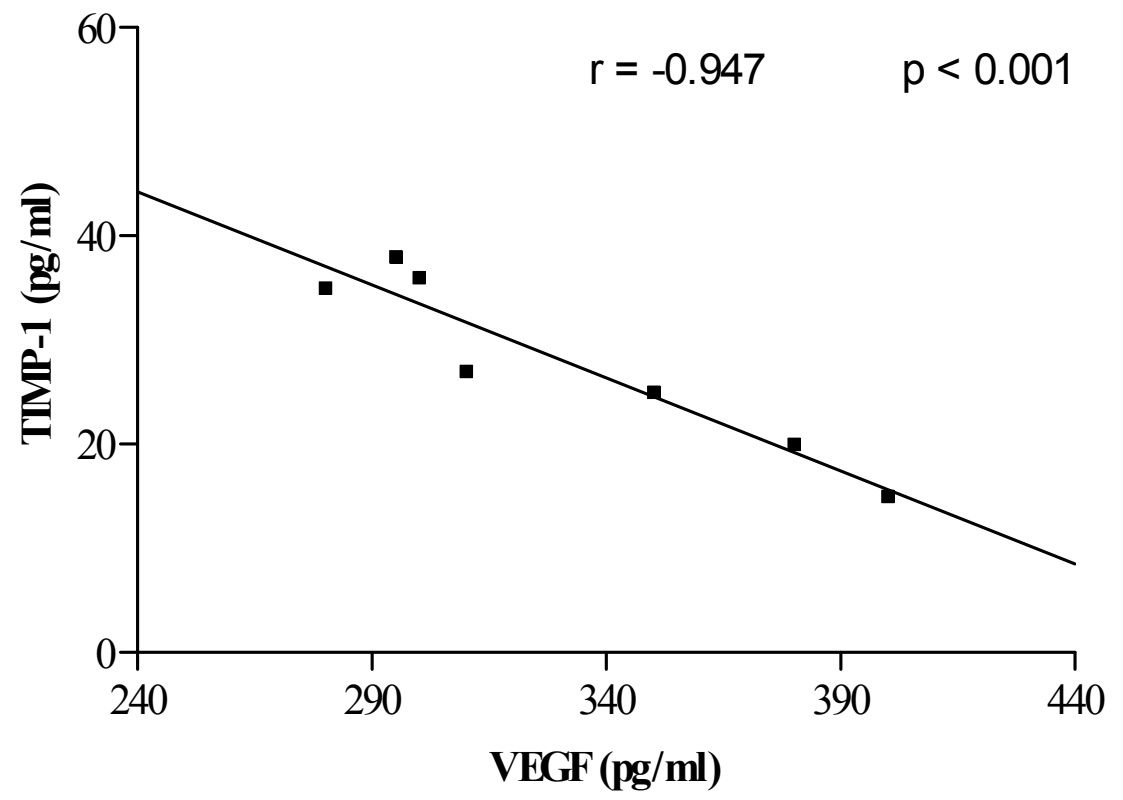

Fig. 5. Correlation between VEGF \& TIMP-1

in raw red chilli + DMH group at 1 month.

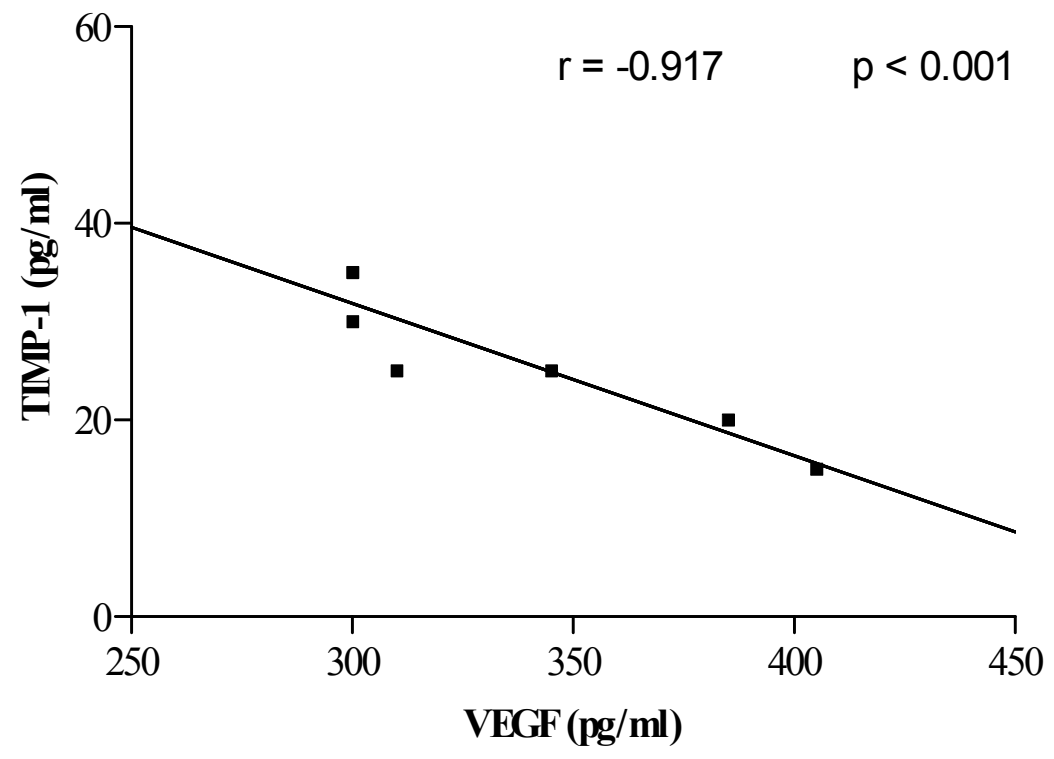

Fig. 6. Correlation between VEGF \& TIMP-1 in raw red chilli + DMH group at 2 months. 
مجلة بحوث التربية النوعية - العدد السادس عشر- يناير. r. r

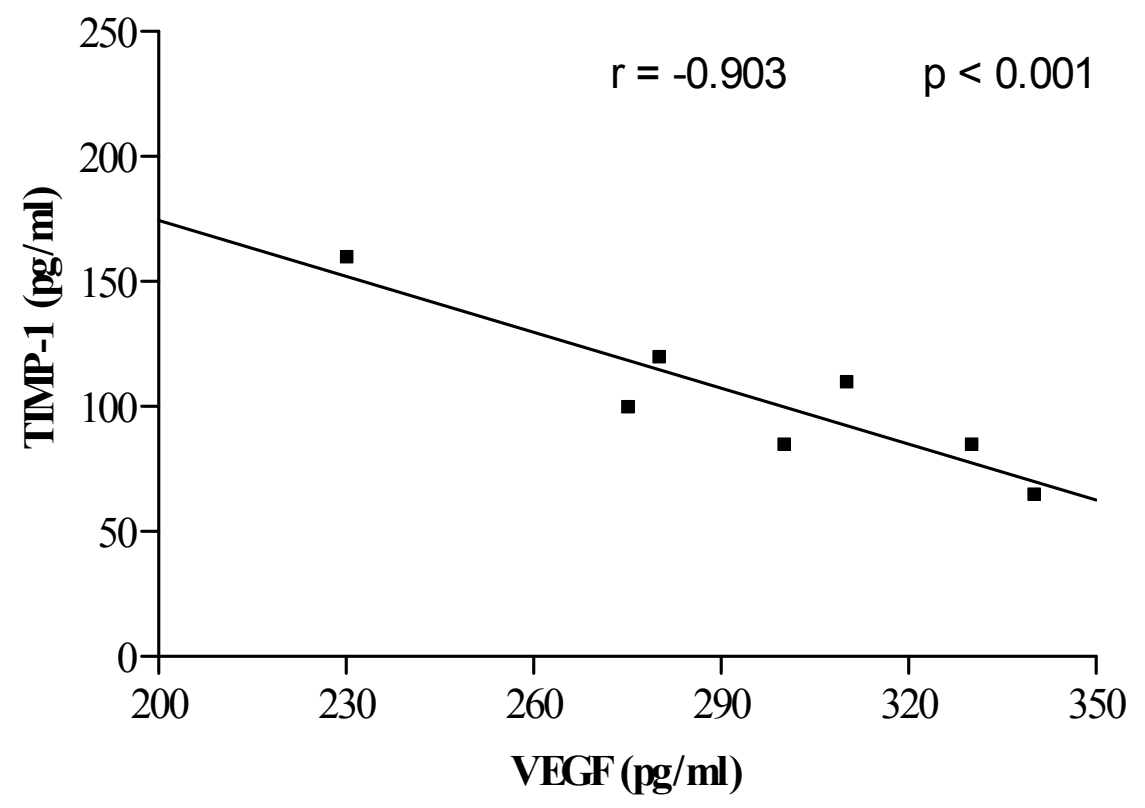

Fig. 7. Correlation between VEGF \& TIMP-1

in gamma red chilli + DMH group at 1 month.

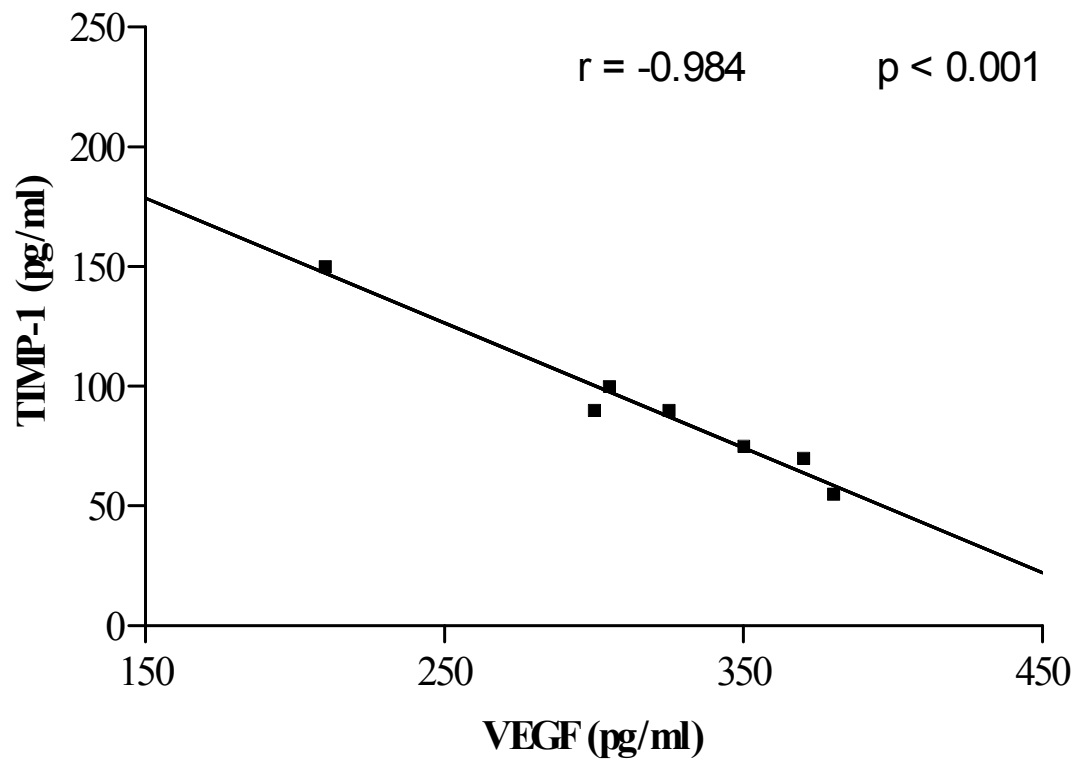

Fig. 8. Correlation between VEGF \& TIMP-1 in gamma red chilli + DMH group at 2 months. 


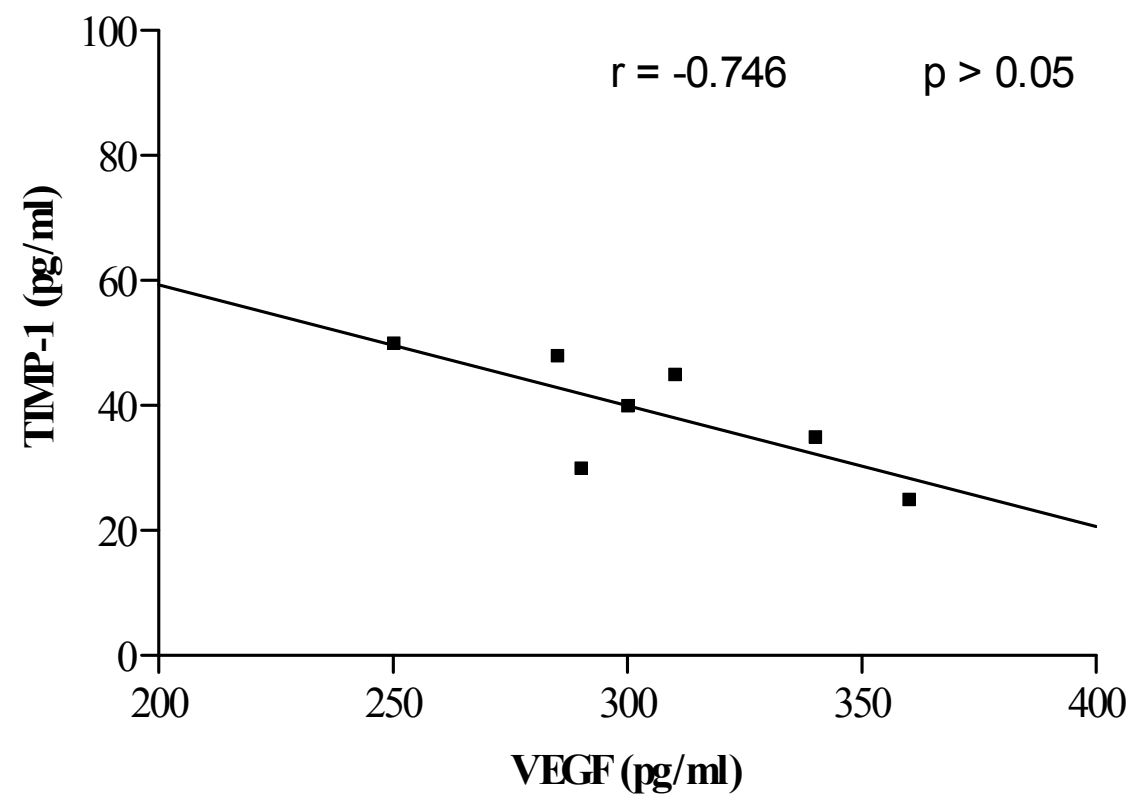

Fig. 9. Correlation between VEGF \& TIMP-1 in microwave red chilli + DMH group at 1 month.

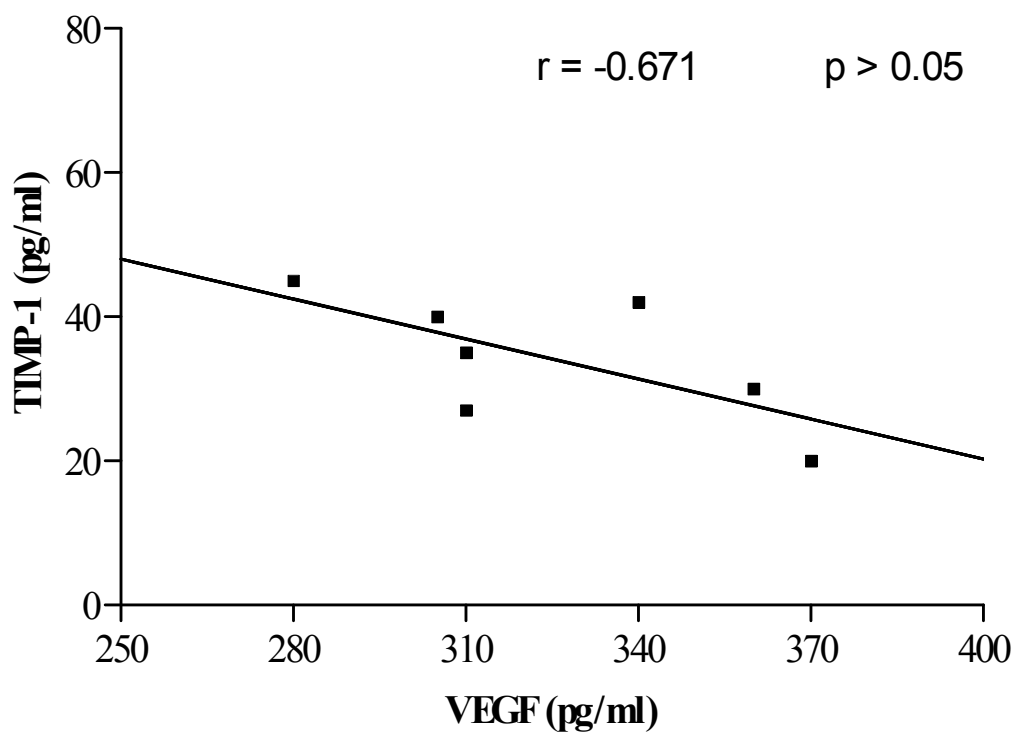

Fig. 10. Correlation between VEGF \& TIMP-1 in microwave red chilli + DMH group at 2 months. 


\title{
تأثير الشطة الهمراء المقاوم للسرطان فى فئران الألبيينو
}

إعـداد

أ.د/ محمد كمال السيد يوسف

أستاذ علوم وتكنولوجيا الأغذية بكلية الزراعة-- جامعة أسيوط وعضو أكاديمية العلوم الأمريكية

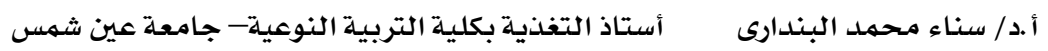

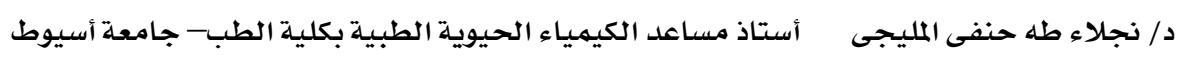

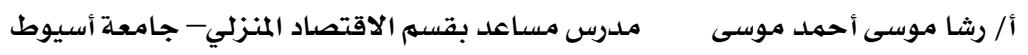

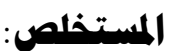

تم تشعيع الشطة الحمراء بنوعين من الأشعة: أشعة جاما وأشعة الميكروويف. وتم دراسة تأثيرهما علي خصائص الشطة الحمراء المقاومة للسرطان أو كعامل مساعد فى علاج مرض السرطان. وأوضحت الدراسة البيولوجية أن تناول الشطة الحمراء تحكم بشكل ملحوظ ِِّ التأثير المسرطن لمادة ثنائي ميثيل هيدرازين، وذلك

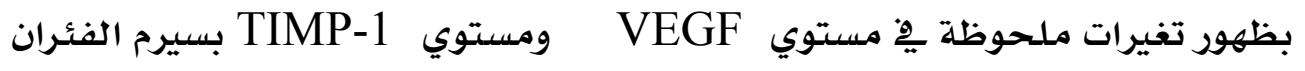
وخاصـة مـع الشطة الحمراء المعالجة بأشعة جاما. كهما أوضحت الدراسة أن تناول الثطة الحمراء بأنواعها قاومت نمو الخلايا السرطانية بعد الحقن بمادة ثنائى ميثيل هيدرازين للفئران. ولهذا يعتبر تناول الشطة الحمراء عادة غذائية لها أكبر الأثر فِ الوقاية من الإصابة بالسرطان أو اعتبارها كعامل مساعد مكمل للعلاج الكيميائي ِِّ الشفاء من مرض السرطان.

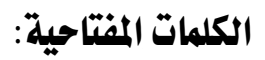

TIMP-1 - VEGF - الشطة الحمراء - ثنائى ميثيل هيدرازين 